Original Research Paper

\title{
Optimalisasi Kemampuan Representasi Matematis Siswa SMA di Tinjau dari Gender/ Jenis Kelamin
}

\author{
Maria Tamo Ina ${ }^{1}$, Ahmad Muzaki ${ }^{2}$, Samuel Rex M. Making ${ }^{3}$ \\ ${ }^{1,2,3}$ Program Studi Pendidikan Matematika, Sekolah Tinggi Keguruan dan Ilmu Pendidikan Weetebula, Indonesia
}

\section{Article history}

Received: 01 October 2021

Revised: 19 October 2021

Accepted: 19 October 2021

*Corresponding Author: Maria Tamo Ina, STKIP Weetebula, Tambolaka, Indonesia; Email: riainna83@gmail.com
Abstrak: Tujuan penelitian ini, untuk mencari informasi dan mengetahui kemampuan representasi matematis siswa SMA ditinjau dari gender/jenis kelamin. Metode yang digunakan adalah metode kepustakaan (library research), data dalam penelitian ini diperoleh melalui membaca, mencatat, serta mengumpulkan data dari berbagai sumber pustaka seperti jurnal, artikel dan sumber lainya yang relevan. Hasil penelitian kemampuan representasi matematis siswa ditinjau dari gender.

Berdasarkan hasil penelitian dari tujuh jurnal, dari 58 siswa yang terdiri dari 26 siswa laki-laki dan 32 siswa perempuan, kemampuan representasi matematis siswa terdapat perbedaan setiap gender. Perbedaan setiap gender dilihat dari cara menyelesaikan soal sesuai dengan indikator dari setiap artikel yang ada dan kemampuan menjawab soal dan menyelesaikan soal hampir sama tetapi cara menjelaskan soal dengan cara yang berbeda. Kemampuan representasi matematis siswa laki-laki hampir sama kemampuan representasi matematis siswa perempuan dalam cara menjawab soal tes, sesuai dengan indikator yang diterapkan

Kata Kunci: kemampuan representasi matematis siswa ditinjau dari gender.

\begin{abstract}
The porpose of this studi, to find infformation and find out the mathematical representation ability of senior high school in terms of gender and gender. The method used is the library research method. The data in this study was obtained through reading, taking notes anda collecting data and various library sources such as jurnals, articles, and other relevant sources. Hanrs experience of mathemattical representation abilities were reviewed and gender.

Based on the results of research from seven journals, from 58 students consisting of 26 male students and 32 fermale students, the mathematical representation ability of stundents is different for each gender. The quenstions are almost the same but the way of explaining the questions is different. The mathematical representation ability of male students is almost the same as the mathematical representation of fermale students in how to answer test quetions, acoording to the indicators applied.

Keywords: mathematical representation ability of students in terms of gender.
\end{abstract}

Keywords: Component; Formatting; Style; Styling; Insert (keywords)

\section{Pendahuluan}

Prihandoko (Hanifah, 2018: 133) menyatakan bahwa ilmu dasar yang menjadi alat untuk mempelajari ilmu-ilmu lain adalah matematika. Matematika sangat penting dalam kehidupan, bahkan setiap hari matematika digunakan oleh manusia dalam kehidupannya untuk menghitung belanja, mengukur dan lain sebagainya. Pentingnya ilmu dasar yang perlu melekat pada mata pelajaran matematika didasari oleh kesadaran siswa yang nantinya berpengaruh terhadap hasil belajar. NCTM (Hanifah, 2018: 133) mengungkapkan bahwa representasi merupakan cara yang digunakan seseorang untuk mengkomunikasikan 
jawaban atau gagasan matematika yang bersangkutan. Menurut Mustangin (Nasrul, 2016: 146) menyatakan bahwa ragam representasi yang sering digunakan dalam mengkomunikasikan matematika antara lain berupa sajian visual seperti tabel, gambar, grafik, pernyataan matematika atau notasi matematika, teks tertulis yang ditulis dengan bahasa sendiri baik formal maupun informal, ataupun kombinasi semuanya. Dari beberapa definisi tersebut dapat disimpulkan bahwa representasi adalah ungkapan-ungkapan dari ide matematika yang ditampilkan siswa sebagai model atau bentuk pengganti suatu situasi masalah yang digunakan untuk solusi dari masalah yang sedang dihadapinya sebagai dari interpretasi pikirannya. Suatu masalah dapat direpresentasikan melalui gambar, kata-kata (verba), tabel, benda kongkrit atau simbol matematika

Setiap individu memiliki ciri khas yang unik dan berbeda dari yang lain, maka setiap gender juga memilik kekurangan dan kelebihannya masing-masing. Gender merupakan jenis kelamin yang mengacu pada dimensi sosial budaya seseorang sebagai laki-laki atau perempuan. Sesuai dengan pendapat Santrock (Sutriyono, 2018) konsep gender adalah sifat laki-laki dan perempuan yang dibentuk oleh faktor-faktor sosial dan budaya. Snowman et al (Vitantri, 2019: 89) menyatakan bahwa hasil penelitian menunjukkan perbedaan antara laki-laki dan perempuan dalam hal pencapaian fungsi kognitif. Jadi, dapat disimpulkan gender merupakan perbedaan sifat yang terletak antara laki-laki dan perempuan yang dibentuk oleh faktor sosial dan budaya. Menurut Mondoh (Hadiyanto, 2017) gender memiliki besar pengaruhnya terhadap hasil belajar siswa karena perbedaan style dari laki-laki dan perempuan, sehingga mengakibatkan perbedaan hasil belajar dari laki-laki dan perempuan tersebut. Sesuai dengan hasil penelitian yang dilakukan oleh Afandi, Purwanti, Weaver-Hightower (Hidayat, 2017: 131) bahwa perbedaan gender tidak berperan dalam kesuksesan belajar, dalam arti tidak dapat disimpulkan dengan jelas bahwa laki-laki atau perempuan lebih baik dalam belajar matematika, dan fakta yang menunjukkan bahwa ada banyak perempuan yang sukses dalam karier matematikanya. Jadi sesuai dengan pendapat para ahli bahwa gender merupakan perbedaan jenis kelamin antara laki-laki dan perempuan yang dibentuk oleh faktor sosial dan budaya serta tidak dipengaruh oleh pencapaian hasil konitif.

Hasil penelitian Fredman dan Carlsmith (Dewi:117) menemukan bahwa laki-laki tampak lebih baik dari pada perempuan dalam kemampuan kuantitatif dan kemampuan pemahaman ruang. Perlu diketahui bersama bahwa kemampuan spasial pada masing-masing siswa tidak sama. Perbedaan yang paling sering diteliti ialah perbedaan berdasarkan jenis kelamin. Ashari (Yumniyati, 2016: 6), ada beberapa penelitian yang menyatakan bahwa terdapat perbedaan signifikan antara laki-laki dan perempuan dalam hal kemampuan penalaran spasialnya, misalnya dalam penelitian yang dilakukan oleh Ganley dan Vasilyeva di tahun 2011. Eisenberg dkk (Nur, 2018: 134) juga mengatakan bahwa laki-laki lebih unggul di dalam bidang matematika dibandingkan dengan perempuan Pentingnya representasi sistem representasi secara kognitif dalam model Goldin digunakan untuk merencanakan, memantau, dan mengendalikan proses pemecahan masalah matematis. Representasi dalam komunikasi matematis dapat membantu proses penyempurnaan pemahaman ide-ide matematika, dan membantu arti dan kekekalan suatu ide. Namun permasalahan yang terjadi adalah kemampuan representasi matematik di tingkat pendidikan SMA belum tertangani akibatnya kemampuan representasi matematik siswa rendah. Rendahnya kemampuan representasi matematis siswa terlihat dari penelitian yang telah dilakukan, oleh Amir (Sri: 2017) menyatakan bahwa representasi siswa masih sangat kurang. Dan kelemahan siswa dalam menyampaikan ide /gagasan serta siswa tidak diberi kesempatan untuk menyampaikan setiap ide/gagasan yang dimiliki sehingga siswa mengalami kesulitan serta ditinjau dari jenis kelamin, sejalan dengan para ahli Hutagaol (Isnarto, 2019) menyatakan bahwa terdapatnya permasalahan dalam penyampaian materi pembelajaran matematika, yaitu kurang berkembangnya daya representasi siswa, khususnya pada siswa SMA, siswa tidak pernah di beri kesempatan untuk menghadirkan representasinya sendiri tetapi harus mengikuti apa yang sudah dicontohkan oleh guru. Kemudian, hasil studi Hudiono dalam Kartini Hutagol dalam jurnal pembelajaran konseptual untuk meningkatkan kemampuan representasi matematis siswa SMP menunjukkan bahwa terjadinya kelemahan representasi siswa seperti tabel, gambar, model disampaikan kepada siswa karena hanya sebagai pelengkap dalam penyampaian materi. Berdasarkan uraian di atas maka, peneliti ini ingin melakukan penelitian yang berjudul optimalisasi kemampuan representasi matematis siswa SMA ditinjau dari gender/jenis kelamin. 


\section{Metode Penelitian}

Jenis penelitian yang digunakan dalam penelitian ini adalah penelitian study literature. (Library Research). Studi literature merupakan serangkaian kegiatan yang berkenaan dengan metode pengumpulan data pustaka, membaca dan mencatat serta mengelola bahan penelitian (Mestika, zed, 2008:3). Penelitian studi literatur ada empat ciri utama yang perlu diperhatikan, yaitu pertama, penulis atau peneliti berhadapan langsung dengan teks, bukan dengan pengetahuan langsung dari lapangan. Kedua, data literatur bersifat "siap pakai" artinya peneliti tidak terjun langsung ke lapangan karena peneliti berhadapan langsung dengan sumber data yang ada. Ketiga, data literatur yang digunakan umumnya data sekunder dalam artian bahwa peneliti memperoleh data atau bahan dari tangan kedua bukan dari pertama di lapangan. Keempat, kondisi data literatur tidak dibatasi oleh ruang dan waktu. (Zed, 2014:4). Teknik analisis data yaitu teknik mengumpulkan data berupa artikel-artikel yang berkaitan dengan topik penelitian, dimulai dengan membaca yang berkaitan dengan topik penelitian yang akan diteliti agar mempermudah dan menemukan konsep yang ingin diteliti, mencatat hal-hal penting dan relevan. Pada tahapan analisis ini, peneliti mencatat hal-hal penting dan relevan dengan permasalahan yang diteliti. Penyajian data adalah usaha untuk menyusun sekumpulan informasi yang telah diperoleh di lapangan, kemudian data tersebut disajikan secara jelas dan sistematis sehingga akan memudahkan dalam pengambilan kesimpulan. Penyajian data ini akan membantu dalam memahami apa yang sedang terjadi dan apa yang harus dilakukan. Penarikan Kesimpulan yaitu dari data yang terkumpul diperoleh suatu kesimpulan.

\section{Hasil dan Pembahasan}

\section{a. Hasil}

Hasil kajian delapan jurnal yang relevan dengan judul penelitian yang mendukung jawaban dari rumusan masalah.

1. Izwita Dewi (2017) analisis peningkatan kemampuan representasi matematis siswa SMA ditinjau dari perbedaan gender.

Instrumen penelitian berupa tes representasi matematis. Berdasarkan hasil penelitian bahwa peningkatan kemampuan representasi matematis pada kategori rendah, dan sedang siswa laki-laki lebih tinggi dari pada siswa perempuan. Berdasarkan hasil analisis data ditinjau dari perbedaan gender menunjukkan ada $30 \%$ siswa laki-laki dan $23 \%$ siswa perempuan yang memiliki peningkatan representasi matematis kategori rendah, sedangkan $70 \%$ siswa laki-laki dan $68 \%$ siswa perempuan memiliki peningkatan representasi kategori sedang. Untuk peningkatan representasi kategori tinggi, tidak ada satu pun siswa laki-laki yang masuk dalam kategori tersebut tetapi ada $9 \%$ siswa perempuan yang masuk kategori tersebut. Indikator yang digunakan dalam kemampuan representasi kemampuan representasi matematis yaitu, 1) model atau ekspresi matematis, 2) representasi visual berupa tabel, 3) representasi visual berupa gambar dan 4) kata-kata atau teks tertulis. Sedangkan indikator pencapaian yaitu 1) menyelesaikan masalah dengan melibatkan ekspresi matematis, 2) menyajikan kembali data atau informasi dari suatu representasi ke representasi tabel, 3) membuat gambar untuk memperjelas masalah dan memfasilitasi penyelesaian, 4) membuat situasi masalah berdasarkan data dan membuat situasi masalah berdasarkan data atau representasi yang diberikan dan menuliskan. Berdasarkan hasil analisis data bahwa hanya terdapat pada indikator 3 saja siswa laki-laki memiliki kemampuan representasi matematis lebih tinggi dari pada siswa perempuan. Hal berarti kemampuan representasi visual dalam membuat gambar siswa laki-laki lebih tinggi dari pada siswa perempuan. Jadi untuk meningkatkan representasi matematis siswa laki-laki yang kategori rendah.

2. Moh. Nasrul Fuad, representasi matematis siswa SMA dalam memecahkan masalah persamaan kuadrat ditinjau dari perbedaan gender instrumen yang digunakan berupa tes. Berdasarkan hasil penelitian analisis data penelitian menunjukkan bahwa siswa laki-laki dan siswa perempuan mampu melakukan representasi matematis dengan baik dan mampu menjawab permasalahan dengan benar. penelitian deskriptif kualitatif, yaitu mengungkapkan dan memberikan gambaran tentang fenomena dari subjek penelitian secara kualitatif yang bertujuan untuk mendeskripsikan secara lengkap representasi matematis siswa SMA dalam memecahkan masalah persamaan kuadrat ditinjau dari perbedaan gender. Subjek penelitian terdiri dari 2 siswa SMA 3 Kediri kelas X pada pelajaran 2015/2016, yaitu satu siswa 
laki-laki dan satu siswa perempuan. Berdasarkan hasil analisis data penelitian menunjukkan bahwa siswa laki-laki dan siswa perempuan mampu melakukan representasi matematis dengan baik dan mampu menjawab permasalahan dengan benar. Akan tetapi siswa laki-laki dan siswa perempuan memecahkan masalah dengan tiga tahap, yakni memahami masalah, menyusun rencana pemecahan masalah, dan melaksanakan rencana pemecahan masalah. Siswa laki-laki tidak melakukan pengecekan kembali hasil penyelesaian masalah yang telah dibuat. Melalui tiga tahap yaitu tahap memahami masalah, menyusun rencana pemecahan masalah, dan melaksanakan rencana pemecahan masalah siswa laki-laki dan perempuan mampu merepresentasikan masalah dengan cara mereka sendiri dengan kepercayaan masing-masing dapat mempermudah dalam menyelesaikan masalah mereka menggunakan kata-kata secara lisan, teks tertulis, maupun penggunaan simbol serta memanipulasinya. Neria Amit (Nasrul, 2016) mengemukakan bahwa proses pemecahan masalah yang sukses bergantung kepada ketrampilan merepresentasikan masalah seperti mengkonstruksi dan menggunakan grafik, tabel, dan persamaan-persamaan penyelesaian dan manipulasi simbol. Dalam pembelajaran matematika, suatu masalah matematika yang sama misalnya diberikan kepada beberapa individu, maka akan mendapatkan respon yang berbeda dalam penyelesaiannya. Terlihat bahwa ketika siswa menyelesaikan masalah, ada beberapa siswa yang harus memvisualisasikan informasi dan ide-idenya menggunakan gambar, ada pula yang memodelkannya dalam bentuk matematika. Semua itu bergantung pada kemampuan matematika yang dimiliki siswa. Siswa laki-laki maupun perempuan akan memiliki representasi yang baik jika siswa tersebut memiliki kemampuan matematika yang baik pula.

3. Uum Umaroh tentang analisis representasi matematis siswa dalam mengerjakan soal PISA ditinjau dari gender metode penelitian deskriptif kualitatif. Instrumen yang digunakan yaitu tes tertulis dan wawancara. Hasil analisis data menunjukkan bahwa terdapat perbedaan kemampuan representasi visual dan simbolik antara subjek laki-laki dan perempuan. Subjek laki-laki mampu merepresentasikan visual dengan cara membuat gambar dengan benar, sedangkan subjek perempuan belum dapat merepresentasikan dalam bentuk gambar. Untuk kemampuan representasi simbolik, subjek perempuan sudah mampu menggunakan persamaan atau model matematika dengan benar, sedangkan subjek lakilaki masih mengalami kekeliruan dalam menggunakan simbol matematika. Untuk kemampuan representasi verbal walaupun subjek perempuan kurang percaya diri dalam menjawab soal, tetapi subjek laki-laki dan perempuan telah merepresentasikan kata-kata atau teks tertulis dengan baik dengan cara menjawab soal dengan benar dan mengungkapkan kembali langkah-langkah pekerjaannya dengan jelas. Tujuan dalam penelitian ini adalah untuk mendeskripsikan kemampuan representasi matematis siswa dalam mengerjakan soal PISA yang ditinjau dari perbedaan gender. Indikator yang digunakan dalam penelitian ini yaitu: Soal 1 untuk mengukur kemampuan representasi visual (gambar, diagram, grafik, atau tabel), soal 2 untuk mengukur kemampuan representasi simbol (pernyataan matematika/notasi matematika, numeric/simbol aljabar), dan soal 3 untuk mengukur kemampuan representasi verbal (teks tertulis/kata-kata). Berdasarkan hasil analisis data bahwa siswa laki-laki mampu soal sesuai dengan 4 indikator soal dan siswa perempuan hanya mampu menjawab soal 3 indikator. Sehingga kemampuan siswa laki-laki lebih tinggi daripada siswa perempuan.

4. Bony Fattah tentang Representasi Matematis Peserta Didik Menurut Pandangan Bruner Dalam Menyelesaikan Soal Geometri Ditinjau Dari Kemampuan Matematika dan Jenis Kelamin. Instrumen yang digunakan berupa tes dan wawancara. Berdasarkan hasil analisis data representasi matematis siswa laki-laki dan siswa perempuan yang memiliki kemampuan matematika tinggi dapat memenuhi ketiga indikator representasi matematis, jadi kemampuan representasi siswa laki-laki dan perempuan pada soal geometri memiliki kemampuan yang sama. Representasi Matematis dapat dilatih dan dikembangkan melalui kebiasaan menyelesaikan soal-soal geometri. Selain itu representasi matematis erat kaitannya dengan kemampuan matematika dan jenis kelamin. Sehingga tujuan penelitian ini adalah untuk mendeskripsikan representasi matematis peserta didik menurut pandangan Bruner dalam menyelesaikan soal geometri ditinjau dari kemampuan matematika (tinggi, sedang, dan rendah) dan jenis kelamin (lakilaki dan perempuan) di SMPN 1 Duduk Sampeyan.

5. Nur Hanifah dan Sutriyono tentang Deskripsi Kemampuan Representasi Matematis Siswa SMP Pada Materi Bangun Datar Ditinjau Dari Perbedaan Gender. Instrumen yang digunakan berupa tes tertulis. 
penelitian kualitatif deskriptif. Subjek dalam penelitian ini adalah siswa kelas VIII-D SMP Negeri 3 Salatiga. Subjek dipilih berdasarkan rekomendasi dari guru matematika kelas VIII-D, subjek telah memenuhi kecukupan pengetahuan dan ketrampilan matematika pada materi bangun datar segi empat. Subjek terdiri dari 3 siswa laki-laki dan 3 siswa perempuan. Keenam siswa tersebut memiliki kemampuan matematika yang sama. Representasi matematis siswa laki-laki pada materi geometri: (1) Pada ekspresi matematis, membuat model matematika dari masalah yang diberikan, sudah membuat model matematika namun masih salah, tetapi terdapat 1 siswa yang sudah membuat model matematika dengan benar. (2) Pada ekspresi matematis, menyelesaikan masalah dengan melibatkan ekspresi matematis, sudah membuat model matematika dengan benar, melakukan perhitungan dengan tepat, namun salah dalam mendapatkan solusi. (3) Pada representasi visual, menyajikan permasalahan ke dalam gambar bangun datar segi empat, terdapat 2 siswa yang membuat gambar akan tetapi tidak lengkap dan siswa lainnya sudah membuat gambar dengan benar dan lengkap. (4) Pada teks tertulis/kata-kata, menjawab soal dengan menggunakan kata-kata, sudah menulis/menjelaskan secara matematis dan logis, akan tetapi tidak tersusun secara sistematis. Representasi matematis siswa perempuan pada materi geometri: (1) Pada ekspresi matematis, membuat model matematika dari masalah yang diberikan, terdapat 1 siswa yang membuat model matematika namun masih salah, tetapi siswa yang lain sudah membuat model matematika dengan benar. (2) Pada ekspresi matematis, menyelesaikan masalah dengan melibatkan ekspresi matematis, sudah membuat model matematika dengan benar, melakukan perhitungan dengan tepat, dan mendapatkan solusi yang benar. (3) Pada representasi visual, menyajikan permasalahan ke dalam gambar bangun datar segi empat, sudah membuat gambar secara benar dan lengkap. (4) Pada teks tertulis/kata-kata, menjawab soal dengan menggunakan kata-kata, terdapat 2 siswa yang penjelasan ditulis/dijelaskan secara matematis akan tetapi tidak lengkap, namun terdapat 1 siswa penjelasan ditulis/dijelaskan akan tetapi masih salah. Berdasarkan hasil analisis data yang diperoleh dalam penelitian bahwa siswa perempuan lebih mampu menyelesaikan soal dengan benar daripada siswa laki-laki.

6. Aswin Burhanudin Sugiyono, tentang representasi matematis siswa dalam menyelesaikan soal model PISA ditinjau dari perbedaan jenis kelamin. Instrumen dalam penelitian ini berupa tes tertulis dan wawancara. berdasarkan analisis data hasil penelitian dalam menyelesaikan soal model PISA matematika siswa laki-laki menggunakan strategi penyelesaian yang singkat sesuai dengan hasil jawaban yang tertulis pada lembar jawaban kedua siswa laki-laki tersebut dalam menyelesaikan soal model PISA. Sedangkan siswa perempuan menggunakan strategi penyelesaian yang rinci sesuai dengan hasil jawaban yang tertulis pada lembar jawaban kedua siswa perempuan tersebut dalam menyelesaikan soal model PISA. Jadi kemampuan representasi matematis siswa perempuan lebih tinggi dari pada kemampuan representasi matematis laki-laki.

7. Susi Hermin Rusminati tentang representasi pemecahan masalah desimal siswa SD ditinjau dari gender. Instrumen yang digunakan berupa tes tertulis dan wawancara. Berdasarkan hasil penelitian Susi ( 2018 ) siswa laki-laki lebih cenderung membaca soal dan menuliskan kembali informasi yang diterima pada soal; yang dibaca kemudian mencari penyelesaiannya dengan menggunakan tangga satuan. Ketika mengerjakan operasi hitung desimal siswa tersebut masih terlihat bingung dan mengerjakan dengan beberapa coretan yang ada di kertasnya. Siswa perempuan ketika menyelesaikan masalah terlebih dahulu membaca kemudian menuangkan rencananya pada lembar jawaban, siswa tersebut langsung menuliskan rencananya tanpa menggunakan gambar. Hal ini dilakukan siswa tersebut karena dalam menyelesaikan soal tidak memerlukan gambar. Terlihat bahwa ketika siswa menyelesaikan masalah ada beberapa siswa yang memvisualisasikan informasi dan ide-idenya menggunakan gambar, ada pula yang memodelkan matematika.

8. Suci Rahma Hamid, Muhammad Sudia, dan Hafiludin Samparadja, tentang profil kemampuan representasi matematik siswa madrasah Aliyah ditinjau dari gaya kognitif dan gender. Instrumen yang digunakan berupa tes tertulis dan wawancara. Berdasarkan hasil penelitian tersebut bahwa siswa lakilaki dan perempuan dengan gaya kognitif reflektif maupun impulsif memiliki kemampuan menginterpretasi fenomena matematik kedalam representasi simbolik yang lebih baik dari pada 
kemampuan mentranslasi representasi visual ke dalam representasi simbol dan kemampuan menggunakan representasi simbol untuk menjelaskan ide-ide matematik.

\section{b. Pembahasan}

Berdasarkan hasil penelitian setiap jurnal yang dikaji peneliti yaitu:

Tabel 1. Kemampuan representasi matematis siswa berdasarkan gender dari setiap artikel

\begin{tabular}{|c|c|c|c|c|}
\hline Artikel & $\begin{array}{c}\text { Jumlah } \\
\text { siswa }\end{array}$ & $\begin{array}{l}\text { Laki- } \\
\text { laki }\end{array}$ & $\begin{array}{l}\text { Perem- } \\
\text { puan }\end{array}$ & Kemampuan Representasi Matematis \\
\hline 1 & 32 & 13 & 19 & $\begin{array}{l}\text { subjek siswa yang diteliti berjumlah } 32 \text { orang yang terdiri } \\
\text { dari } 13 \text { orang siswa laki-laki dan } 19 \text { orang siswa perempuan. } \\
\text { Berdasarkan hasil tes peningkatan kemampuan representasi } \\
\text { matematis siswa perempuan lebih tinggi dari pada siswa laki- } \\
\text { laki }\end{array}$ \\
\hline 2 & 2 & 1 & 1 & $\begin{array}{l}\text { Berdasarkan hasil tes penelitian menunjukkan bahwa } \\
\text { kemampuan representasi matematis siswa meningkat karena } \\
\text { siswa laki-laki dan perempuan sama-sama menjawab soal } \\
\text { sesuai dengan indikator. }\end{array}$ \\
\hline 3 & 2 & 1 & 1 & $\begin{array}{l}\text { Berdasarkan hasil analisis data yang peroleh bahwa } \\
\text { kemampuan siswa laki-laki lebih tinggi daripada siswa } \\
\text { perempuan. }\end{array}$ \\
\hline 4 & 6 & 3 & 3 & $\begin{array}{l}\text { Berdasarkan hasil analisis data yang peroleh bahwa } \\
\text { kemampuan representasi siswa laki-laki dan perempuan pada } \\
\text { soal geometri memiliki kemampuan yang sama }\end{array}$ \\
\hline 5 & 6 & 3 & 3 & $\begin{array}{l}\text { Berdasarkan hasil yang diperoleh dalam penelitian bahwa } \\
\text { siswa perempuan lebih unggul dari pada siswa laki-laki } \\
\text { dalam representasi berupa pernyataan matematika atau } \\
\text { notasi matematika, siswa perempuan lebih unggul daripada } \\
\text { siswa laki-laki dalam representasi visual yang berupa } \\
\text { gambar, siswa laki-laki lebih unggul daripada siswa } \\
\text { perempuan dalam representasi berupa teks tertulis/kata-kata }\end{array}$ \\
\hline 6 & 4 & 2 & 2 & $\begin{array}{l}\text { berdasarkan hasil penelitian bahwa menunjukkan siswa laki- } \\
\text { laki dan perempuan sama-sama memiliki kemampuan } \\
\text { representasi matematis tinggi }\end{array}$ \\
\hline 7 & 4 & 2 & 2 & $\begin{array}{l}\text { Berdasarkan hasil penelitian dari } 4 \text { siswa bahwa kemampuan } \\
\text { siswa laki-laki berbeda dengan kemampuan siswa } \\
\text { perempuan. }\end{array}$ \\
\hline 8 & 2 & 1 & 1 & $\begin{array}{l}\text { Berdasarkan hasil analisis data yang diperoleh bahwa siswa } \\
\text { laki-laki dan perempuan memiliki kemampuan representasi } \\
\text { yang sama. }\end{array}$ \\
\hline Jumlah & 58 & 256 & 32 & \\
\hline
\end{tabular}

Berdasarkan hasil penelitian dari delapan jurnal, dari 58 siswa yang terdiri dari 26 siswa laki-laki dan 32 siswa perempuan, kemampuan representasi matematis siswa terdapat perbedaan setiap gender. Perbedaan setiap gender dilihat dari cara menyelesaikan soal sesuai dengan indikator yang ada dan kemampuan menjawab soal dan menyelesaikan soal hampir sama tetapi cara menjelaskan soal dengan cara yang berbeda. Kemampuan representasi matematis siswa laki-laki hampir sama kemampuan representasi matematis siswa perempuan dalam cara menjawab soal tes, sesuai dengan indikator yang diterapkan. Kemampuan representasi siswa matematis siswa laki-laki dalam menjawab soal hanya 
mampu mencapai tiga indikator. Demikian siswa perempuan juga hanya mampu menjawab soal tiga indikator. Adanya perbedaan kemampuan representasi matematis pada siswa laki-laki dengan perempuan dimana representasi matematis pada tahap memahami masalah, dari apa yang diketahui representasi matematis yang dihasilkan siswa berupa kombinasi antara teks tertulis dan simbol. Sedangkan dari apa yang ditanyakan representasi matematis yang dihasilkan siswa yaitu berupa simbol dan juga berupa teks tertulis. Pada tahap menyusun masalah representasi matematis siswa yang dihasilkan siswa berupa persamaan matematis dan juga kata-kata secara lisan. Pada tahap melaksanakan rencana pemecahan masalah langkah-langkah pemecahan masalah direpresentasikan oleh siswa ke dalam bentuk persamaan matematika dan simbol aljabar.

\section{Kesimpulan dan Saran}

Berdasarkan hasil dan pembahasan kajian delapan artikel menunjukkan bahwa kemampuan representasi matematis siswa laki-laki lebih unggul dalam bidang matematika, dibandingkan dengan kemampuan representasi matematis siswa perempuan. Karena memiliki kemampuan-kemampuan ruang yang lebih baik dan cara berpikir logis, sedangkan kemampuan representasi matematis siswa perempuan masih kurang.

Berdasarkan kesimpulan di atas maka saran yang berikan peneliti untuk meningkatkan kemampuan representasi matematis siswa SMA ditinjau dari gender, maka penulis mengharapkan agar guru mata pelajaran matematika dapat memperhatikan kemampuan representasi siswa laki-laki dan perempuan pada pembelajarannya dalam materi apa pun, begitu pula bagi guru mata pelajaran lainnya.

\section{Daftar Pustaka}

Dewi Izwita, Saragih S. Khairani D. 2017. Analisis Peningkatan Kemampuan Representasi Matematis Siswa SMA Ditinjau dari Perbedaan Gender;ISSN 2355-4185(p), 2548-8546.

Fattah B, Zawawi I, Midjan, 2018 representasi matematis peserta didik menurut pandangan bruner dalam menyelesaikan soal geometri ditinjau dari kemampuan matematika dan jenis kelamin. Vol.24, Nomor 2.

Fuad Moh Nasrul. 2016. Representasi Matematis Siswa SMA dalam Memecahkan Masalah Persamaan Kuadrat Ditinjau dari Perbedaan Gender. Jurnal Matematika Kreatif-Inovatif http://journal.unnes.ac.id/nju/index.php/kreano

Hamid S. R., Sudia M, \& Hafiludin Samparadja H, 2020. Profil Kemampuan Representasi Matematik Siswa Madrasah Aliyah Ditinjau Dari Gaya Kognitif Dan Gender. Vol. 5, No. 1, Mei 2020: 51-64.

Hanifah N, Sutriyono. 2018. Deskripsi kemampuan matematis siswa SMP pada materi bangun datar ditinjau dari perbedaan gender. Volume 5 No1.

Hidayat W, Rohaeti E. E, Dilla C. S. 2017. Faktor gender dan resiliensi dalam pencapaian kemampuan berpikir kreatif matematis siswa SMA. Jurnal, volume 2, No. 1.

Isnarto M. M. R. N. 2019. Kemampuan representasi matematis dalam model pembelajaran somatic, Auditory, Vsualization, Intellectually. ISSN 2613-9189.

Rusminati S. H, 2018 Representasi Pemecahan Masalah Decimal Siswa SD Ditinjau Dari Gender. Vol. II. No 1.

Umaroh Uum. Pujiastuti H, 2020. Analisis kemampuan reprensentasi matematis siswa dalam mengerjakan soal PISA ditinjau dari perbedaan gender, Jurnal pendidikan Matematika raflesia.volume. 05. No. 02.

Zed, Mestika 2014, Metode Penelitian Kepustakaan, Jakarta: Yayasan Obor Indonesia 